\title{
PEMANFAATAN LINDI HITAM HASIL ISOLASI LIGNIN DARI TANDAN KOSONG KELAPA SAWIT SEBAGAI ANTI MIKROBA
}

\author{
Muhammad Ferdiansyah Mulya Harahap ${ }^{1}$, Sri Hidayati ${ }^{2}$, dan Subeki ${ }^{2}$ \\ ${ }^{1}$ Magister Teknologi Industri pertanian Pertanian, Universitas Lampung \\ ${ }^{2}$ Departemen Teknologi Hasil Pertanian, Universitas lampung \\ Email: srihidayati.unila@gmail.com
}

\begin{abstract}
ABSTRAK
Telah dilakukan isolasi lignin dari lindi hitam hasil proses pulping menggunakan metode formacell dari tandan kosong kelapa sawit. Hasil monomer dari pemecahan lignin diduga memiliki senyawa yang bersifat anti mikroba. Penelitian ini bertujuan untuk mengetahui pengaruh konsentrasi hasil pemecahan monomer lignin dengan perlakuan $0 \%, 2,5 \%, 5 \%, 7,5 \%, 10 \%, 12,5 \%$, dan $15 \%$ terhadap daya hambat sebagai antimikroba. Hasil penelitian menunjukkan bahwa proses pemurnian menggunakan fraksi $3 \% \mathrm{MeOH}: \mathrm{CHCl}_{3}$ pada konsentrasi 12,5 dan $15 \%$ memiliki aktivitas antimikroba yang sama dan tertinggi terhadap E. coli dengan diameter zona hambat sebesar $6,33 \mathrm{~mm}$, sedangkan aktivitas antimikroba terendah terhadap E. coli dimiliki fraksi $3 \% \mathrm{MeOH}: \mathrm{CHCl}_{3}$ pada konsentrasi 2,5\% dengan diameter zona hambat sebesar 5,17 $\mathrm{mm}$.

Kata Kunci-antimikroba; isolasi; lignin; lindi hitam
\end{abstract}

\section{PENDAHULUAN}

Indonesia merupakan penghasil kelapa sawit nomor satu dunia dengan produksi sawit diperkirakan mencapai 34,5 juta ton pada tahun 2018. Potensi TKKS sangat besar yaitu dalam satu ton tandan buah segar (TBS) yang diolah akan dihasilkan tandan Kosong Kelapa Sawit (TKKS) sekitar 23\% dari tandan buah segar (Darnoko, 1992). TKKS memiliki kadar selulosa 50\%, lignin $16 \%$ dan hemiselulosa $19,6 \%$ sehingga TKKS berpotensi untuk dijadikan alternatif pembuatan pulp non kayu pengganti pulp kayu (Hidayati et al., 2017). Salah satu permasalahan pada industri pulp dan kertas adalah adanya limbah yang dikenal sebagai lindi hitam yang sangat mencemari lingkungan. Lindi hitam dapat diisolasi baik secara asam, alkohol maupun metode basa untuk mendapatkan lignin yang murni.

Lindi dapat diisolasi dengan menggunakan metode asam maupun basa. Isolasi lignin dari lindi hitam TKKS menggunakan $\mathrm{NaOH}$ 30\% menghasilkan padatan sebanyak 65,11\% (Lin et al., 1992; Hidayati et al., 2018). Karakteristik kimia lignin dapat diperoleh dengan analisis unsur dan penentuan gugus metoksil. Jumlah gugus metoksil dalam lignin bergantung pada sumber lignin dan proses isolasi yang digunakan (Ayyachamy et al., 2013). Hasil isolasi lignin dapat dimanfaatkan secara komersial menjadi karbon fiber, adhesif, poliuretan, poliester, bioplastik, dan bio oil untuk campuran minyak bumi dari fosil, sebagai anti bakteri dan antioksidan (Bonini et al., 2005; Kleinert and Barth, 20087; Xu et al., 2006; Ayyachamy et al., 2013). Monomer lignin dari tanaman softwood mengandung phenol yang seperti carvacrol, thymol dan cinnamaldehyde yang diduga dapat menghambat pertumbuhan mikroba (Smid et al., 1996; Ultee et al., 2000; Skandamis et al., 2001; Smith-Palmer et al., 2001; Roller and Seedhar, 2002; Lee et al., 2004; Bozin et al., 2006; Doherty et al., 2011; Sriroth and Sunthornvarabhas, 2018) sehingga diharapkan dapat berfungsi sebagai obat yang memiliki kemampuan sebagai anti mikroba yang bisa diharapkan sebagai pengganti obat sintetik atau penicillin yang sudah dilarang penggunaannya. Senyawa fenolik ini juga tidak bisa digunakan sebagai sumber karbon untuk pertumbuhan bakteri patogen dan diduga memiliki efek antimikroba dengan mengurangi laju pertumbuhan bakteri pathogen (Prayuwidayati et al., 2016; Lee et al., 2004; Bozin et al., 2006). Senyawa fenol dan flavonoid hasil pecahan monomer lignin dari tanaman softwood bersifat sebagai anti mikroba dan bersifat antibiotik (Baurhoo et al., 2008).

Kelebihan lignin sebagai anti mikroba adalah bersifat renewable, mudah teruraikan oleh lingkungan dan ketesediaannya berlimpah di alam (Mollahosseini et al., 2012; Bakkali et al., 2008). Hasil monomer dari lignin dengan proses alcell dapat menghambat pertumbuhan bakteri (Phillip et al., 2000) Selain itu Alcell lignin mengurangi konsentrasi Escherichia coli dalam kotoran unggas bila dibandingkan dengan diet bebas antibiotik atau yang mengandung antibiotic (Baurhoo et 
al., 2008). Lignin dari hasil isolasi limbah cair pulp berbahan baku TKKS belum banyak diteliti terutama pemanfaatannya sebagai antimikroba sehingga diharapkan penelitian ini bermanfaat selain untuk memanfaatkan limbah pencemar. Tujuan penelitian ini adalah mengetahui pengaruh konsentrasi lignin hasil isolasi terhadap daya hambat bakteri.

\section{METODOLOGI PENELITIAN}

\section{A. Alat dan Bahan}

Alat dan bahan yang digunakan dalam penelitian adalah TKKS, asam asetat glasial, Piridin, $\mathrm{CHCL}_{4}, \mathrm{HPO}_{3}, \mathrm{KMNO}_{4}, \mathrm{KI}, \mathrm{Na}_{2} \mathrm{~S}_{2} \mathrm{O}_{3}, \mathrm{HCl}, \mathrm{H}_{2} \mathrm{SO}_{4}(72 \%)$, indikator amilum 0,2\%. Alat yang digunakan adalah reaktor, alat soxhlet apparatus, GC-MS dan alat analisis lain

\section{B. Pelaksanaan Penelitian \\ 1. Pemasakan pulp}

Pemasakan pulp dilakukan dengan menggunakan proses formacell. Sebanyak $1000 \mathrm{~g}$ TKKS dimasukkan dalam rotary digester (alat pemasak). Kondisi pemasakan mengacu pada penelitian (Hidayati et al., 2016) yaitu menggunakan rasio asam asetat $1: 14$. Suhu maksimum $150^{\circ} \mathrm{C}$ dengan waktu 90 menit, waktu pada suhu maksimum 90 menit. Pulp disaring dengan menggunakan Hidrolic Screener. Filtrat yang berupa liquor atau lindi hitam dilakukan proses pemurnian.

\section{Ekstraksi Pemurnian Lignin}

Endapan lignin didegradasi menggunakan $\mathrm{CuSO}_{4}$, pridin, dan $\mathrm{H}_{2} \mathrm{O}_{2}$. Sebanyak $2 \mathrm{~g}$ endapan lignin dilarutkan dengan $20 \mathrm{~mL}$ larutan $\mathrm{NaOH} \mathrm{pH}$ 12. Sebanyak $25 \mathrm{~mL} \mathrm{CuSO}_{4} 10^{-2} \mathrm{M}$ dan $5 \mathrm{~mL}$ piridin ditambahkan ke dalam larutan lignin. Larutan diaduk dengan pengaduk magnetik selama 30 menit, setelah itu ditambahkan $10 \mathrm{~mL} \mathrm{H}_{2} \mathrm{O}_{2} 1 \mathrm{M}$ sebanyak 5 kali dengan jarak waktu 30 menit. Selanjutnya larutan diaduk di ruang gelap selama 72 jam. Filtrat yang telah difraksinasi selanjutnya dievaporasi hingga diperoleh residu. Residu kemudian dilarutkan dalam $500 \mathrm{~mL} \mathrm{H} 2 \mathrm{O}$ dan diekstraksi dengan EtOAc $500 \mathrm{~mL}$ sebanyak 3 kali hingga diperoleh lapisan $\mathrm{H}_{2} \mathrm{O}$ dan EtOAc. Lapisan EtOAc dievaporasi hingga diperoleh residu. Residu kemudian dimasukkan ke dalam silika gel kolom kromatografi dan dielusi dengan 3\% $\mathrm{MeOH}: \mathrm{CHCL}_{3}$

\section{Uji antimikroba}

Pengujian anti mikroba dilakukan dengan menggunakan bakteri E. coli. Peubah yang diamati pada masing-masing senyawa monomer lignin yaitu uji zona hambat dengan metode difusi cakram. Uji zona hambat dilakukan pada bakteri patogen dengan metode difusi agar. Kultur disegarkan terlebih dahulu dalam tabung yang berisi medium NB steril dan diinkubasi 24 jam pada $37^{\circ} \mathrm{C}$. Sebagai stok bakteri, dibuat kultur bakteri dalam agar miring dengan medium NA, disimpan di dalam lemari pendingin setelah terlebih dahulu diinkubasi selama 24-48 jam.

Setiap stok bakteri yang akan digunakan dalam pengujian aktivitas antibakteri, selalu disegarkan kembali di dalam medium NB steril selama 24 jam $37^{\circ} \mathrm{C}$, dihomogenkan dengan alat vorteks, lalu diinokulasikan sebanyak $20 \mu \mathrm{l}$ ke dalam labu Erlenmeyer yang berisi $20 \mathrm{~mL}$ medium

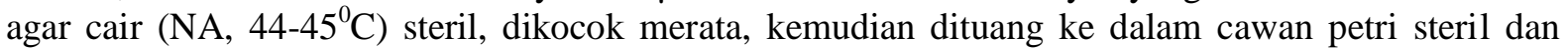
dibiarkan sampai membeku. Selanjutnya letakkan kertas cakram yang sudah disterilisasi terlebih dahulu di atas media agar. Fraksi monomer lignin yang akan diuji dibuat konsentrasi dengan menggunakan pelarut aquades sebesar $0 \%, 2,5 \%, 5 \%, 7,5 \%, 10 \%, 12,5 \%$, dan $15 \%$.

\section{Pengamatan}

Zona penghambatan yang diukur adalah radius (r, $\mathrm{mm}$ ) penghambatan berupa areal beining di sekeliling kertas cakram, setelah diinkubasi selama 1 hari pada $37^{\circ} \mathrm{C}$. Pengukuran jari-jari zona hambat di sekeliling sumur uji dilakukan dengan cara mengukur jarak dari tepi kertas cakram uji ke batas lingkaran zona hambat menggunakan jangka sorong (ketelitian $0,01 \mathrm{~mm}$ ) pada beberapa sisi kertas cakram, perhitungan dilakukan dengan menghitung rata-rata dari data yang diperoleh. 


\section{HASIL DAN PEMBAHASAN}

\section{Aktivitas Antimikroba Fraksi 3\% $\mathrm{MeOH}: \mathrm{CHCl}_{3}$ terhadap bakteri Eschericia coli}

Fraksi 3\% $\mathrm{MeOH}: \mathrm{CHCl}_{3}$ diuji aktivitas antimikroba pada berbagai konsentrasi 0\%, 2,5\%, 5\%, 7,5\%, 10\%, 12,5\%, dan 15\%. Masing-masing fraksi diteteskan sesuai konsentrasinya ke bagian atas kertas cakram yang diletakan di atas permukaan Nutrient Agar sebagai media pertumbuhan Eschericia coli dalam cawan petri. Pengamatan diameter zona hambat dilakukan setelah 24 jam dan diukur dengan menggunakan jangka sorong. Berdasarkan hasil pengukuran diameter zona hambat masing-masing konsentrasi fraksi $3 \% \mathrm{MeOH}: \mathrm{CHCl}_{3}$ terhadap Eschericia coli dapat dilihat pada Gambar 1.

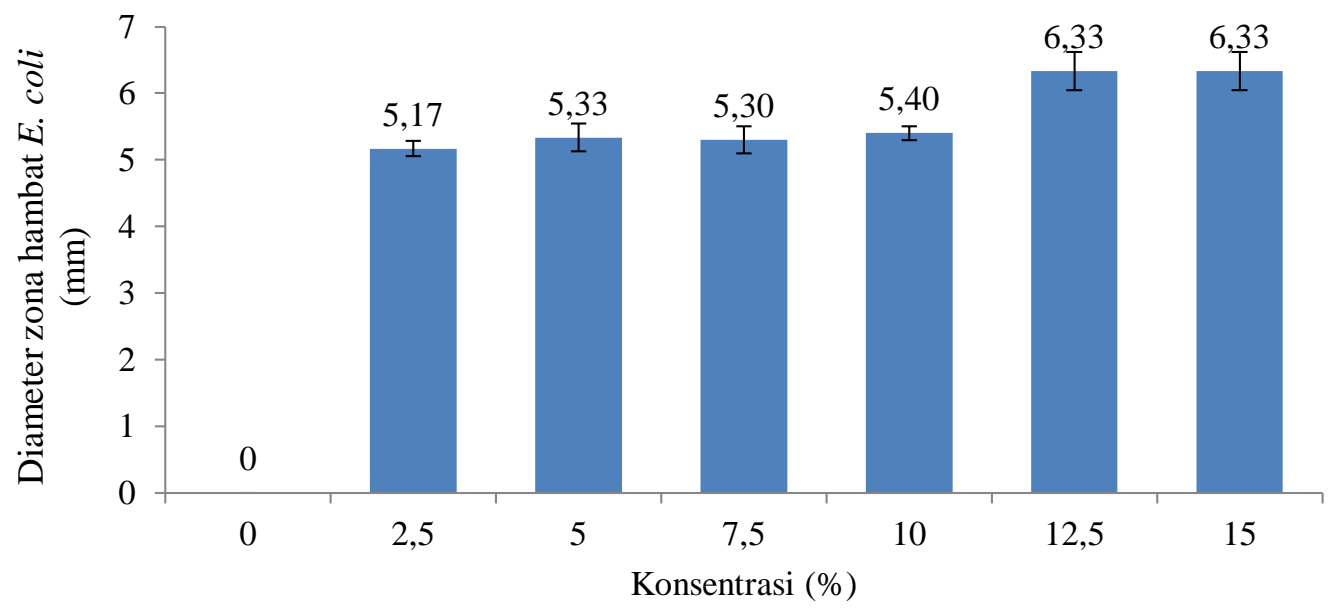

Gambar 1. Pengaruh Berbagai Konsentrasi Fraksi 3\% MeOH:CHCl 3 terhadap Diameter Zona Hambat Bakteri Eschericia coli

Gambar 1 menunjukkan bahwa fraksi 3\% $\mathrm{MeOH}: \mathrm{CHCl}_{3}$ pada konsentrasi $0 \%$ tidak memiliki aktivitas antimikroba terhadap E. coli. Hal ini ditunjukkan dengan tidak terbentuknya zona hambat disekeliling kertas cakram. Fraksi $3 \% \mathrm{MeOH}: \mathrm{CHCl}_{3}$ pada konsentrasi 12,5 dan $15 \%$ memiliki aktivitas antimikroba yang sama dan tertinggi terhadap E. coli dengan diameter zona hambat sebesar $6,33 \mathrm{~mm}$, sedangkan aktivitas antimikroba terendah terhadap E. coli dimiliki fraksi $3 \% \mathrm{MeOH}: \mathrm{CHCl}_{3}$ pada konsentrasi $2,5 \%$ dengan diameter zona hambat sebsesar $5,17 \mathrm{~mm}$. hasil yang sama ditunjukkan oleh Alzagameem et al., 2019) yang menyatakan bahwa peningkatan konsentrasi lignin dapat meningkatkan aktifitas gugus fungsi seperti $\mathrm{OH}$ alifatik, $\mathrm{CO}$ karbonil dan $\mathrm{COOH}$ sedangkan konsentrasi lignin dalam jumlah yang kecil belum mampu bertindak sebagai aantimikroba pada $\mathrm{E}$ Coli. Zona hambat yang terbentuk pada uji aktvitas antimikroba fraksi $3 \% \mathrm{MeOH}: \mathrm{CHCl}_{3}$ terhadap $E$. coli dapat dilihat pada Gambar 2.

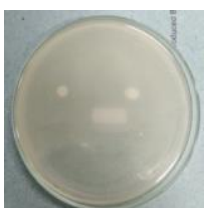

a

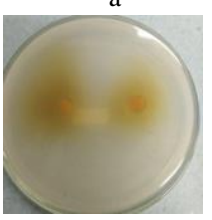

$\mathrm{e}$

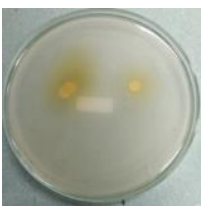

b

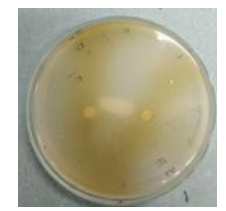

$\mathrm{f}$

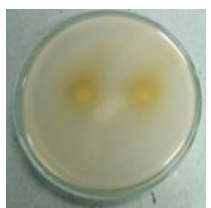

$\mathrm{c}$

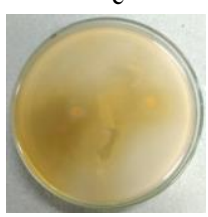

$\mathrm{g}$

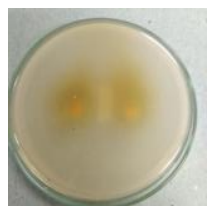

d

Gambar 2. Zona Hambat yang Terbentuk pada Uji Aktivitas Antimikroba Fraksi 3\% $\mathrm{MeOH}: \mathrm{CHCl}_{3}$ terhadap Eschericia coli. a) $0 \%$, b) $2,5 \%$; c) $5 \%$; d) $7,5 \%$; e) $10 \%$; f) $12,5 \%$ dan g) $15 \%$ 
Adanya senyawa antioksidan dan antibakteri yang terdapat di dalam fraksi hasil isolasi lignin dapat menghambat pertumbuhan mikroba. Lignin mengandung gugus aktif hidroksi phenolic, epoksi dan metoksil yang bersifat antimikroba (Yang et al., 2016; Lupoi et al., 2015; Alzagameem et al., 2018: Kaur et al, 2017). Komponen antibakteri seperti golongan benzene, bersifat sebagai antibakteri (Bartolomeazzi et al., 2007), seperti 1,2 benzenedicarboxylic acid,bis(2- methylpropyl) ester, benzenepropanoic acid,3,5-bis (1,1 dimethylethyl)-4-hydoxy-,methyl ester. Komponen fenolik seperti phenol,2-(1-methylpropyl)-,methylcarbamate, m-anisic acid,3,4-dichlorophenyl ester, dan phenol,2methyl-4-(1,1,3,3-tetramethylbutyl)- adalah komponen yang bersifat antimikrobial (Soldera et al., 2008; Kristinsson et al., 2007; Gomez-Estaca, 2007; Milly et al., 2005, Muratore and Licciardello, 2005; Sunen et al., 2003, Sunen et al., 2001).

Penghambatan bakteri terjadi karena fenol menyerang sel vegetatif berprenetasi dan merepresitifikasi protein yang terdapat dalam sel mikroba dan adannya interaksi antara ikatan hidrogen dengan protein penyusun enzim (Saravanakumar et al., 2009). Beberapa jenis asam, seperti asam anisic dan asam karbamat, diduga sebagai antibakteri. Lefroi, 2000; Rorvik, 2000) mengatakan bahwa senyawa aldehid, asam karboksilat dan fenol mempunyai sifat antimikrobial dan antioksidan. Senyawa fenol dan flavonoid hasil pecahan monomer lignin dari tanaman softwood bersifat sebagai antimikroba dan antibiotik (Roller and Seedhar, 2002). Philip (2000), menyatakan bahwa hasil monomer dari lignin dengan proses alcell dapat menghambat pertumbuhan bakteri E. coli, S. aureus, dan Pseudomonas. Senyawa fenol dari lignin dapat merusak dinding mikroba dan menyebabkan lisis pada bakteri diikuti pelepasan konten sel (Sabu, 2011).

Pada fraksi terdapat asam lemak jenuh dan tak jenuh yang memiliki atom karbon lebih dari sepuluh yang dapat mengakibatkan terhambatnya pertumbuhan bakteri atau kematian pada bakteri patogen yang diujikan (Hou, 2000). Asam lemak yang memiliki aktvitas antimikroba adalah 9hexadecanoic acid (Agoramoorthy et al., 2007). Senyawa 9-hexadecanoic acid memberikan efek terhadap permeabilias membran dan partisi ion ada lapisan membran sel dari mikroorganisme (Lagner and Hui, 2000). Senyawa dari golongan benzene juga memiliki aktivitas penghambatan terhadap pertumbuhan mikroorganisme. Suzuki et al., (1988) menyatakan bahwa senyawa di-2-ethylhexyl phthalate dapat bereaksi dengan sisi hidrofobik pada membran sel yang menyebabkan terganggunya permeabilitas dari membran sel. Hasil identifikasi komponen monomer lindi hitam hasil isolasi yang diduga mengandung senyawa anti mikroba disajikan pada Tabel 1. Berdasarkan Tabel 1. Senyawa yang diduga bersifat sebagai antimikroba dalam jumlah cukup banyak pada lignin yaitu Benzaldehyde,4-hydroxy-3,5-dimethoxysebesar 2,76\%, m-Anisic acid,3,4-dichlorophenyl ester sebesar 1,1\%, golongan phenol lain seperti Phenol,2-methyl-4-(1,1,3,3- tetramethylbutyl)-sebesar 0,71\%, Di-2-ethylhexyl phthalate sebesar 31,25\% dan 9-Hexadecenoic acid, methyl ester,(Z)- sebesar $0,41 \%$. Hal ini yang menyebabkan semakin tinggi konsentrasi lignin yang digunakan dapat meningkatkan daya hambat sebagai antimikroba (Gambar 2) karena meningkatnya konsentrasi antimikroba didalam larutan lignin tersebut.

Tabel 1. Identifikasi senyawa hasil isolasi dari monomer lignin yang bersifat antimikroba

\begin{tabular}{llll}
\hline No & Nama senyawa & Berat molekul & Jumlah (\%) \\
\hline 1 & Phenol,2-(1-methylpropyl)-,methylcarbamate & 207 & 0,12 \\
2 & Benzoic acid,4-hydroxy-3-methoxy- & 214 & 1,04 \\
3 & Benzaldehyde,4-hydroxy-3,5-dimethoxy & 222 & 2,76 \\
4 & p-Anisic acid,4-nitrophenyl ester & 182 & 0,32 \\
5 & m-Anisic acid,3,4-dichlorophenyl ester & 273 & 0,9 \\
6 & m-Anisic acid,3,4-dichlorophenyl ester & 296 & 1,1 \\
7 & Phenol,2-methyl-4-(1,1,3,3- tetramethylbutyl)- & 220 & 0,3 \\
8 & Phenol,2-methyl-4-(1,1,3,3- tetramethylbutyl)- & 220 & 0,71 \\
9 & 1,2-Benzenedicarboxylic acid,bis(2- methylpropyl) ester & 278 & 0,7 \\
10 & 9-Hexadecenoic acid, methyl ester,(Z)- & 268 & 0,41 \\
11 & 1-Methylbutyl hexadecanoate & 326 & 41,03 \\
12 & Di-2-ethylhexyl phthalate & 390 & 31,25 \\
\hline
\end{tabular}




\section{KESIMPULAN}

Peningkatan konsentrasi ligin dapat meningkatkan daya hambat terhadap mikroba. Penghambatan tertinggi terjadi konsentrasi lignin sebesar 12,5 dan $15 \%$ memiliki aktivitas antimikroba yang sama terhadap E. coli dengan diameter zona hambat sebesar 6,33 mm. Hasil isolasi lignin mengandung senyawa antimikroba yaitu Benzaldehyde,4-hydroxy-3,5-dimethoxysebesar, mAnisic acid,3,4-dichlorophenyl ester, Phenol,2-methyl-4-(1,1,3,3- tetramethylbutyl), Di-2-ethylhexyl phthalate sebesar 31,25\% dan 9-Hexadecenoic acid, methyl ester,(Z)-.

\section{DAFTAR PUSTAKA}

Alzagameem, A., Klein, S.E., Bergs, M., Do. X.T., Korte, I., Dohlen, S. ., , Cuwe, Kreyenschmidt, J Kamm, B., Larkins, M \& Schulze, M., 2019. Antimicrobial Activity of Lignin and Lignin-Derived Cellulose and Chitosan Composites against Selected Pathogenic and Spoilage Microorganism. Polymers (Basel). 11(4:. 670. doi: 10.3390/polym11040670

Alzagameem A., El Khaldi-Hansen B., Kamm B., Schulze M. 2018. Lignocellulosic Biomass For Energy, Biofuels, Biomaterials, and Chemicals. In: Vaz S. Jr., editor. Biomass and Green Chemistry. 1st ed. Springer International Publishing; Basel, Switzerland: 2018. pp. 95-132.

Agoramoorthy, G; Chandrasekaran, M; Venkatesalu, M \& Hsu, M.J., 2007. Bacterial and Antifungal Activities Of Fatty Acid Methyl Esters Of The Blind-Your -Eye Mangrove From India. Brazilian Journal of Microbiology, 38: 739-742

Ayyachamy, M; Finola,E., Cliffe, Jessica, M., Coyne, John Collier, \& Maria G. T., 2013. Lignin: Untapped Biopolymers In Biomass Conversion Technologies. Biomass Conversion and Biorefinery, 3 (3): 255.

Bakkali, F., Averbeck, S., Averbeck, D.,\& Idaomar, M., 2008. Biological Effects of Essential Oils. Review. Food and Chemical Toxicology, 46: 446-475.

Bartolomeazzi, R., Senastianutto, N., Toniolo, R \& Pizzariello, A., 2007. Comparative Evaluation of The Antuoxidant Capacity of Smoke Flavouring Phenols Bycrocin Bleaching Inhibition, DPPH Radical Scavenging and Oxidation Potential. Food Chemistry. 100: 1481 - 1489.

Baurhoo B, C.A., Ruiz-Feria, \& Zhao, X., 2008. Purified Lignin: Nutritional and Health Impacts On Farm Animals. A review Animal Feed Science and Technology. 144: 175-184

Bonini, C., Auria, M; Emmanuel, L., Ferri, R., Pucciarello, R \& Sabia, A.R., 2005. Polyutrethanes and Polyester from Lignin. J.Appl.Polym.Sci. 98 (3): 1451-1456.

Bozin, B., Mimica-Dukic, N., Simin, N., \& Anackov, G., 2006. Characterization of The Volatile Composition of Essential Oils of Some Lamiaceae Spices and The Antimicrobial and Antioxidant Activities of The Entire Oils. J.Agric. Food Chem. 5: 1822-1828.

Darnoko. 1992. Potensi Pemanfaatan Limbah Lignoselulosa Kelapa Sawit melalui Biokonversi. Berita Penelitian Perkebunan. 2 (2): 85-87.

Doherty, W.O.S., Mousavioun, P \& Fellows, C.M., 2011. Value-adding to Cellulosic Ethanol: Lignin Polymers. Industrial Crops and Products, 3: 259-276.

Gomez-Estaca, J., Montero, P., Gimenez, B. \& Gomez-Guillen, M.C., 2007. Effect of Functional Edible Films and High Pressure Proccessing on Microbial and Oxidative Spoilage in ColdSmoked Sardine (Sardina pilchardus). Food Chemistry. 105: 511-520.

Hidayati, S., Zuidar, S., \& Fahreza, A. 2016. Optimasi Produksi Pulp Formacell dari Tandan Kosong Kelapa Sawit (TKKS) dengan Metode Permukaan Respon, Reaktor, 16(4):161-171.

Hidayati, S., Zuidar \& Satyajaya. 2017. Effect of Acetic Acid: Formic Acid Ratio on Characteristics of Pulp From Oil Palm. ARPN Journal of Engineering and Applied Sciences. 12 (12): 38023807.

Hidayati, S., Zuidar, A.S., Satyajaya, W., Murhadi \& Retnowati, D.,. 2018. Isolation and Characterization Of Formacell Lignins From Oil Empty Fruits Bunches. IOP Conf. Series: Materials Science and Engineering 344. 2018.

Hou, C, T., 2000. Biotransformation of Unsaturated Fatty Acids to Industrial Products. Advances in Applied Microbiology. 47:201-220

Kleinert, M \& Barth, T., 200 8. Towards in Lignicellulosic Biorefinery: Direct One Step Conversion of Lignin to Hydrogen-Enriched Biofuel. Energy Fuels. 22 (2): 1371-1379. 
Kaur, R., Uppal, S.K., \& Sharma, P. 2017. Antioxidant and Antibacterial Activities of Sugarcane Bagasse Lignin and Chemically Modified Lignins. Sugar Tech. 19:.675-680. doi: 10.1007/s12355-017-0513-y.

Kristinsson, H.G., Danyali, N.,\& Ua-Angkoon, S., 2007. Effect of Filtered Wood Smoked Treatment on Chemical and Microbial Chages in Mahi-mahi fillets. Journal of Food Science. 72:16-24.

Langner M. and Hui S.2000),Effect of Free Fatty Acids On The Permeability Of 1, 2-imyristoyl-SnGlycero-3-Phosphocholine Bilayer At The Main Phase Transition BBA-. Membranes,1463, 439-447.

Lee, K.W., Everts, H.,\& Beynen, A.C., 2004. Essential oils in broiler nutrition. Inter. J. Poult. Sci. 3 : $738-752$.

Leroi, J.J.J., 2000. Salt and Smoke Simultaneously Effect Chemical and Sensory Quality of ColdSmoked Salmon during $5^{\circ}$ Celcius Storage Predicted using Factorial Design. Journal of Food Protection. 63: 1222-1227.

Lin, S. Y. \& Dence, C.W., 1992. Methods in Lignin Chemistry. Berlin Heidelberg : Springer-Verlag.

Lupoi J.S., Singh, S., Parthasarathi R., Simmons B.A., \& Henry R.J., 2015. Recent Innovations In Analytical Methods for The Qualitative and Quantitative Assessment of Lignin. Renew. Sustain. Energy. 4: 871-906. doi: 10.1016/j.rser.2015.04.091.

Milly, P.J., Toledo, R.T., \& Ramakrishnan, S., 2005. Determination of Minimum Inhibitory Concentrations of Liquid Smoke Fractions. Journal of Food Science. 70: 12-17.

Mollahosseini, A., Rahimpour, A., Jahamshahi, M., Peyravi, M \& Khavarpour, M., 2012. The Effect of Silver Nanoparticle Size on Performance and Antibacteriality of Polysulfone Ultrafiltration Membrane. Desalination, 30: 41-50.

Muratore G, \& Licciardello, F., 2005. Effect of Vacuum and Modifed Atmosphere Packaging on the Shelf-lige Off Liquid-Smokeds Word Fish (Xiphiasgladius) slices. Journal of Food Science. 68: 1155-1160.

Phillip , L. E., Idziak, E. S. \&. Kubow, S., 2000. The potential use of lignin in animal nutrition, and in modifying microbial ecology of the gut. Pages 1-9 in East. Nutr. Conf. Anim. Nutr. Assoc. of Canada, Montreal, Quebec, Canada.

Prayuwidayati, M., Sunarti., T. C., Sumardi, Subeki, \& Wiryawan, K. G., K. G., 2016. Use of Lignin Formacell of Empty Bunch Palm Fiber as Feed Supplement and Prebiotics Candidate in Ruminant. Pakistan Journal of Nutrition, 15 (1): 58-65.

Roller, S., \& Seedhar, P., 2002. Carvacrol and Cinnamic Acid Inhibit Microbial Growth in Fresh-Cut Melon and Kiwifruits at $4{ }^{\circ} \mathrm{C}$ and $8{ }^{\circ} \mathrm{C}$. Lett. Appl. Microbiol. 35: 390-394.

Rovrik, L.M., 2000. Listeria Monocytogenes In The Smoked Salmon Industry. International Journal of Food Microbiology. 62: 183-190.

Sabu, T., Visakh, P.M. \& Mathew, A.P., 2011. Advances in Natural Polymers:Composites and Nanocomposites. Springer, Dordrecht.

Saravanakumar, A., Venkateshwaran, K., Vanitha, J., Ganesh, M., Vasudevan, M., \& Sivakumar, T., 2009. Evaluation of Antibacterial Activity Phenol and Flavonoid Contents of The Spesia Populnae Flower Extracts. Pakistan Journal of Phamaceutical Science, 22: 282-286.

Skandamis, P.N., \& Nychas, G., 2001. Effect of Oregano Essential Oil on Microbiological and Physio-Chemical Attributes of Minced Meat Stored in Air And Modified Atmospheres. J. Appl. Microbiol. 9: 1011-1022.

Smith-Palmer, A., Stewart, J., \& Fyfe, L., 2001. The potential application of plant essential oils as natural food preservatives in soft cheese. Food Microbiol. 18: 463-470.

Smid, E.J., Hendriks, I., Boerrigter, H.A.M., \& Gorris, L.G.M., 1996. Surface Disinfection of Tomatoes Using The Natural Plant Compound Trans-Cinnamaldehyde. Postharvest Biol. Tech. 9: 343-350.

Sriroth \& Sunthornvarabhas. 2018, Lignin from Sugar Process as Natural Antimicrobial Agent. Biochem Pharmacol. 7 (1): 1-4.

Soldera, S., Sebastianutto, N., \& Bortolomeazzi, R., 2008. Composition of Phenolic Compounds and Antioxidant Activity of Commercial Aqueois Smoke Flavorings. Journal of Africulture and Food Chemistry. 56: 2727-2734. 
Sunen, E., Aristimuni, C., \& Fernandez-Galian, B., 2003. Activity of Smoke Wood Condesates against Aeromonas hydrophila and Listeria monocytigenesin vacuum-packed, Cold-Smoked Rainbow Trout Storedat $4^{\circ} \mathrm{C}$. Food Research International. 36: 111-116.

Sunen, E., Fernandez-Galian, B., \& Arustumuno, C., 2001. Antibacterial Activity of Smoke Wood Condesates Againts Aeromonas Hydrophila, Yersinia Enterolitica an Listeria Monocytiogenes at Low Temperature. Food Microbilogy. 18: 387-383.

Suzuki, K., Nakano, N., Tanaka, R., Uyeda, M., \& Shibata, M., 1988. Cell Aggregation Factor Produced by Streptomyces sp. Strain No. A-3315. Agricultural and Biological Chemistry. 52(10): 2589-2595

Ultee, A., Slump, R.A., Steging, G., \& Smid, E.J., 2000. Antimicrobial activity of $\quad$ carvacrol toward Bacillus cereus on rice. J. Food Prot. 63: 620-624.

Xu, F., Sun, J., Sun, R., Fowler, P., \& Baird, M.S., 2006. Comparative Study of Organosolve Lignin From Wheat Straw. Ind. Crops Product. 23 (2): 180-193.

Yang W., Fortunati E., Dominici F., Kenny J.M., Giovanale G., Mazzaglia A., Balestra G.M., \& Puglia, D., 2016. Effect of Cellulose and Lignin on Disintegration, Antimicrobial and Antioxidant Properties Of PLA Active Films. Int. J. Biol. Macromol. 89: 360-368. doi: 10.1016/j.ijbiomac.2016.04.068. 